\title{
Zadrugarstvo u Hrvatskoj: trendovi, pokazatelji i perspektiva u europskom kontekstu
}

\author{
Zdenko Babić \\ Pravni fakultet u Zagrebu \\ Studijski centar socijalnog rada \\ zbabic@pravo.hr
}

\section{Domagoj Račić}

Mreža znanja d.o.o.

domagoj.racic@mrezaznanja.hr

\begin{abstract}
SAŽETAK Premda zadrugarstvo i socijalna ekonomija u Hrvatskoj imaju dugu povijest, razdoblja socijalizma i tranzicije ostavila su negativan trag na njihov razvoj. $\mathrm{Na}$ temelju provedene analize ključnih pokazatelja poslovanja zadruga u Hrvatskoj, rad pruža ocjenu trenutnog stanja u ovom sektoru hrvatskog gospodarstva. Također, donosi se prikaz stanja i najnovijih tendencija u ovom području u zemljama iz europskog okruženja. Uporabom komparativne analize stanja sektora zadrugarstva i socijalne ekonomije u Hrvatskoj i europskim zemljama ocjenjuju se razvojni potencijali i iznose preporuke za nositelje ekonomske i socijalne politike s ciljem optimalizacije razvoja ovog sektora u Hrvatskoj u budućnosti.
\end{abstract}

Ključne riječi: zadrugarstvo, socijalna ekonomija, Hrvatska

\section{Uvod}

Iako zadrugarstvo i socijalna ekonomija u Hrvatskoj imaju dugu povijest, razdoblja socijalizma i tranzicije ostavila su negativan trag na njihov razvoj. U ovom članku daje se uvid u trenutno stanje zadrugarstva u Hrvatskoj te usporedba tendencija u ovom sektoru gospodarstva sa zemljama iz europskog okruženja. Iz usporedbe i ocjene sadašnjeg stanja sektora u Hrvatskoj i Europi prikazuju se i potencijali za razvoj ovog sektora u Hrvatskoj u budućnosti.

Uloga zadruge je da posluje kao "produžena ruka" njezinih članova, odnosno pomoćni pogon članova koji sa svojih gospodarskih jedinica prenose određene gospodarske funkcije, kao što su nabava, prodaja ili prerada, na zadrugu. Suvremene 
zadruge sa svojim članovima sklapaju poslove (npr. otkup proizvoda), a s druge strane nastupaju na tržištu i sklapaju poslove s trećim osobama. Zadruge osim navedenog prerađuju i trećim osobama prodaju proizvode preuzete od članova (Avsec, 2005.). Upravo po suradnji s članovima zadruge, ona se razlikuje od društva kapitala koje u pravilu ne uspostavlja poslovne odnose sa svojim članovima, a katkad su ti odnosi čak i zabranjeni.

Zadruge imaju značajan potencijal kao instrument socio-ekonomske reintegracije. One ne mogu dati sveobuhvatno rješenje socijalnih i ekonomskih problema tranzicijskog gospodarstva, ali mogu imati značajnu ulogu u povećanju zaposlenosti i Životnog standarda skupina s niskim prihodima te jačanju obnove i razvoja zajednice (Borzaga i Spear, 2004.:186).

Stvaranje zadruga smanjuje zapreke koje ograničavaju manje zajednice i poslovne subjekte. Članovi zadruga udruživanjem postaju dovoljno veliki da mogu nastupiti na novom, većem ili čak međunarodnom tržištu. Zadruge svojim djelovanjem članovima mogu smanjiti transakcijske troškove ili povećati dobit kroz ostvarivanje veće prodaje, snižavanje troškova nabave ili druge koristi. Udruživanjem u zadrugu može se postići veća kolektivna snaga u pregovaranju. Putem zadruga članovi mogu lakše pristupiti potrebnim informacijama i znanjima te tako povećati efikasnost i konkurentnost. Međusobno učenje novih vještina i tehnologija može pridonijeti kvaliteti i vrijednosti proizvoda članova zadruge. Članstvom u zadruzi poduzetniku se otvara mogućnost lakšeg pribavljanja kapitala za investicije ili upravljanje likvidnošću. (Tratnik i sur, 2005.).

Udruživanje u zadruge otvara vrata malim poduzetnicima da izađu na nova tržišta, prošire proizvodnju, poboljšaju profitabilnost i kvalitetu proizvoda, osiguraju nova radna mjesta te se upravo zbog toga može reći da one predstavljaju mehanizam cjelokupnog ekonomskog razvoja. Postojanje i djelovanje zadruga ima značajan doprinos u poboljšanju nekoliko bitnih segmenata gospodarstva. Zajedničko djelovanje pojedinih članova preko uspješno upravljane zadruge može poboljšati potražnju za proizvodima ili uslugama zadrugara čime se direktno utječe na veću agregatnu potražnju u nekom gospodarstvu. Kvalitetna povezanost i upravljanje zadrugama dovodi do bolje poslovne efikasnosti članova zadruga, poboljšavanja kvalitete i prepoznatljivosti proizvoda. To u konačnici rezultira većim zadovoljstvom potrošača i većom prodajom. Udruživanje članova u zadruge poboljšava konkurentnost i otvara sposobnost izlaska na nova tržišta. Otvara se mogućnost izlaska na međunarodno tržište malim proizvođačima, a time i doprinosi poboljšanju vanjskotrgovinske bilance. Osim navedenog postoji veliki potencijal unutar zadružnog sektora koji doprinosi poboljšanju lokalnog i regionalnog razvoja jer su članovi zadruga obično koncentrirani unutar određene lokalne zajednice (Hannsman 1999; Nilsson 2001.)

U nastavku članka donosi se prikaz razvoja sektora zadrugarstva u izabranim zemljama Europske unije. Razrađuje se zakonodavno-institucionalna infrastruktura u izabranim zemljama članicama te na razini Europske unije, opisuje se stanje u 
sektoru zadrugarstva i socijalne ekonomije te donosi prikaz temeljnih tendencija i potencijala za razvoj ovog sektora u budućnosti.

U trećem dijelu donosi se prikaz povijesnog razvoja sa posebnim osvrtom na prikaz razvoja zakonodavne i institucionalne infrastrukture sektora zadrugarstva u Hrvatskoj. Na temelju podataka Hrvatskog saveza zadruga analiziraju se temeljni pokazatelji poslovanja zadruga u Hrvatskoj te donosi ocjena doprinosa ovog sektora gospodarstva ukupnom gospodarstvu u Hrvatskoj, sa osvrtom na perspektivu punopravnog članstva u Europskoj uniji. Na kraju se iznose temeljni zaključci i preporuke za nositelje ekonomske i socijalne politike koje su nastale kao rezultat učinjene analize.

\section{Zadrugarstvo i socijalna ekonomija u Europskoj uniji}

U Europskoj uniji pojam zadruge označava autonomnu dobrovoljnu organizaciju u okviru koje se okupljaju članovi kako bi ostvarili zajedničke ekonomske, socijalne i kulturološke ciljeve kroz demokratski vođenu organizaciju u njihovom vlasništvu.

Osnovne karakteristike zadruga su:

- mogućnost slobodnog, otvorenog i dobrovoljnog udruživanja i povlačenja iz zadružnog poduzeća;

- demokratsku strukturu u kojoj svaki član ima jedan glas, odluke se donose na temelju volje većine, a izabrano vodstvo odgovara članovima zadruge;

- pravedna raspodjela dobiti te

- autonomnost i nezavisnost.

Zadruge postoje kako bi ispunjavale potrebe svojih članova koji zadrugama doprinose svojim kapitalom, ulozima i kontrolom poslovanja. Uglavnom sva poduzeća posluju u cilju zastupanja interesa većinskih vlasnika, odnosno investitora. No, u zadrugama je povrat na kapital obično podređen drugim socijalnim i ekonomskim interesima samih zadrugara. U tom svjetlu, poduzeća bi mogli opisati kao udruživanje kapitala, dok bi zadruge mogli opisati kao udruživanje ljudi.

Važnost zadruga u gospodarstvu Europske unije vidljiv je i u značajnim tržišnim udjelima u različitim sektorima u većini zemalja članica, kao što suํㅗ

poljoprivreda (83\% u Nizozemskoj, 79\% u Finskoj, 55\% u Italiji i 50\% u Francuskoj);

- Šumarstvo (60\% u Švedskoj i 31\% u Finskoj);

- bankarski sektor (50\% u Francuskoj, 37\% na Cipru, 35\% u Finskoj, 31\% u Austriji i $21 \%$ u Njemačkoj);

1 Dostupno na http://ec.europa.eu/enterprise/policies/sme/promoting-entrepreneurship/ social-economy/co-operatives/index_en.htm 
- trgovina / maloprodaja (potrošačke zadruge u Finskoj imaju tržišni udio od 36\%, a u Švedskoj 20\%);

- farmaceutska industrija (21\% u Španjolskoj i 18\% u Belgiji);

- informacijske tehnologije;

- stanovanje i

- zanatska proizvodnja.

Prema istim podacima Europske komisije, u Italiji zadruge imaju udio od gotovo 15\% u ukupnom gospodarstvu. Veliku ulogu zadruge također imaju u uslužnom sektoru, na primjer u pružanju ugostiteljskih, računovodstvenih, pravnih i marketinških usluga za skupine poduzeća (na primjer vodoinstalateri, frizeri, taksisti i sl.) Posljednjih godina organizacijski oblik zadruge ima sve veću ulogu u djelatnostima općeg interesa kao što su obrazovanje, promet i energija.

Međunarodni zadružni savez je na svom Manchesterskom kongresu održanom 1995. godine usvojio "Identity Page" kojim definira osobine današnjih zadruga (MacPherson, 1995.). Dokument je uzrokovao brojne rasprave i pitanja koja sežu u daleku prošlost, još od nastanka međunarodnog zadružnog pokreta i vezana su uz povijesne razlike i različita tumačenja zadruga i njihove uloge u gospodarstvu. Dokument također definira različite postojeće tipove zadruga - potrošačke, radničke, poljoprivredne, financijske, ribarske i stambene, kao i nove tipove zadruga - socijalne, ekološke i rekreacijske zadruge. Ponovno se javljaju rasprave o odnosu zadrugarstva i ideologija (demokratski socijalizam, marksizam, liberalizam, konzervativizam i anarhizam). Otvorena su i pitanja uloge demokracije u zadrugama diljem svijeta, koja su uzrokovala različite rasprave o odnosima sa državom, pogotovo s obzirom na sve manju ulogu države u današnjem vremenu. Također su ponovno postavljena pitanja osnovne svrhe i obveza koje karakteriziraju razvoj zadruga, kao i preispitivanja još nekih poznatih pitanja - odnosi između zadruga i socijalne obveze zadružnog pokreta ${ }^{2}$. Društvene i ekonomske promjene redefiniraju položaj i strategije zadruga, ali im otvaraju i nove mogućnosti. Primjerice, kako se uloga uloga države smanjuje, stvaraju se nove zadruge sa ciljem zadovoljavanja socijalnih potreba u zdravstvu, brizi za starije i brizi za osobe iz rizičnih skupina.

\subsection{Zakonodavno-institucionalni okvir}

U nastavku se iznose osnovne karakteristike zakonodavstva vezanog uz poslovanje zadruga u zemljama članicama Europske unije a temelje se na radu "Study on the implementation of the Regulation 1435/2003 on the Statute for European Cooperative Society (SCE)" koji je nastao kao rezultat istraživanja Cooperatives Europe,

2 ISSAN (2004.), "Trends and challenges for co-operatives and social enterprises in developed and transition countries", Trento, Italija. 
EUCRISE (European Research Institute on Cooperative and Social Enterprises) i EKAI CENTER, objavljenog u listopadu 2010. godine.

Europske zemlje imaju posebne zakone o zadrugama iako u mnogima egzistiraju i zadruge osnovane u skladu sa Statutom europskih zadruga. Statut europskih zadruga je usvojen je 22. srpnja 2003. godine u cilju pružanja adekvatnog pravnog okvira poslovanju zadruga kako bi se olakšale i pojednostavile njihove prekogranične i transnacionalne aktivnosti. Važno je naglasiti da SCE predstavlja dodatni pravni oblik $i$ ne zamjenjuje postojeće zakone kojima se uređuju zadruge na nacionalnoj ili regionalnoj razini. Statut je nastao kao rezultat dvadesetogodišnjih pregovora zadružnog pokreta i Europske komisije, kao i pregovora u okviru samog zadružnog pokreta.

Statut europskih zadruga sastoji se od propisa kojima su detaljno definirana pravila osnivanja i upravljanja europskim zadrugama te direktive (Council Directive, 2001.) koja ocrtava formalnosti u skladu s kojima zaposlenici moraju sudjelovati u donošenju najvažniji odluka na razini organizacije kroz informiranje, savjetovanje i sudjelovanje u radu tijela zadruge. Osim poslovanja zadruga, Statut europskih zadruga također uređuje udruživanje svih vrsta poduzeća s namjerom ostvarivanja zajedničkih koristi, kao što su ulazak na nova tržišta, postizanje ekonomije razmjera, zajedničke razvojne aktivnosti i slično. Statutom je omogućeno udruživanje minimalno pet fizičkih ili dvije pravne osobe iz različitih zemalja Europske unije u europsku zadrugu (SCE). Europsku zadrugu može osnovati i postojeća zadruga koja ima podružnicu u drugoj europskoj zemlji.

Europska zadruga je, poput svih zadruga, pravna osoba čiji članovi (fizičke ili pravne osobe) obavljaju različite aktivnosti zajedno dok u isto vrijeme zadržavaju svoju neovisnost. Članovi europskih zadruga najčešće su klijenti ili dobavljači zadruge i direktno su uključeni u izvršavanje aktivnosti zadruge, kao i u upravljanje zadrugom. Osnovna obveza zadruge je zadovoljavanje potreba njenih članova i/ ili ekonomski i socijalni razvoj, a ne ostvarivanje dobiti. Članovi ostvaruju koristi proporcionalno obimu svog djelovanja i doprinosu aktivnostima zadruge.

Minimalni kapital iznosi EUR 30.000. Osnivači mogu biti klijenti i dobavljači zadruge, a u nekim slučajevima čak i investitori u zadrugu koji ne koriste njene usluge. Glasačka prava takvih investitora - članova su ograničena. S poreznog gledišta, SCE se tretira kao bilo koja druga multinacionalna kompanija sukladno nacionalnom fiskalnom zakonodavstvu primjenjivom na tvrtku ili njenu podružnicu (Council Regulation, 2003.).

Citirano istraživanje iz uvoda pokazalo je sljedeće:

- $\quad$ europske zemlje uglavnom imaju posebne zakone o zadrugama, jedinu iznimku predstavlja Irska;

- većina europskih zemalja ima opći zakon o zadrugama, iako su u nekim zemljama zadruge regulirane općim propisima, građanskim propisima (Italija, 
Nizozemska) ili trgovačkim propisima (Češka, Slovačka), dok je Portugal jedini primjer reguliranja zadruga pravilnikom o zadrugama;

- posebni zakoni (ili pravilnici), koji postoje u nekim zemljama, mogu se temeljiti na vrsti sektora (ovisno o vrsti robe ili usluge koju pruža zadruga, na primjer zadruga banaka), na svrsi samog poslovanja zadruge (ovisno o prirodi cilja poslovanja, na primjer socijalne zadruge) ili na specifičnoj prirodi odnosa između zadruge i njenih članova (na primjer zadruga radnika).

S obzirom na mogući sadržaj propisa o zadrugama iz komparativne perspektive, pregled zakona na snazi u zemljama uključenima u istraživanje pokazalo je da:

- postoje i liberalni i vrlo strogi zakoni u pogledu zadružnih principa i slobode koja je ostavljena statutima zadruga;

- postoje djelomično različiti pogledi na fenomen zadruga, u skladu s različitim načinima na koje se financijski i socijalni aspekti kombiniraju u zakone o zadrugama: u nekim slučajevima prevladava financijski aspekt, odnosno zadruga može slobodno raspodjeljivati dobit u unosu na uplaćeni kapital, a imovina pripada članovima u slučaju raspuštanja zadruge i slično. No, u ovakvim slučajevima zadruga u većini slučajeva nema poseban porezni tretman.

- ako socijalni aspekt ima veću ulogu, zadruga je obvezna u obzir uzimati i druge interese osim isključivog interesa članova ili ne-financijske interese članova (na primjer obrazovanje) a ne samo interese svojih članova. U ovakvim pak slučajevima zadruga često ima specijalni porezni tretman i podliježu zasebnom obliku kontrole (iako je to često slučaj u zakonodavstvu koje slijedi financijski aspekt).

Mnoge zemlje u Europskoj Uniji pod okriljem vlade imaju tijelo s izravnim odgovornostima za pitanja socijalne ekonomije i zadrugarstva. Tako primjerice u Belgiji postoji državni tajnik za održivi razvoj i socijalnu ekonomiju, a u Španjolskoj u sklopu mjerodavnog ministarstva postoji odjel za socijalnu ekonomiju, u Italiji djeluje Ured opće uprave za zadruge unutar Ministarstva gospodarskog razvoja, a u Ujedinjenom Kraljevstvu Uprava za socijalno poduzetništvo. Slična institucionalna rješenja te postavljanje uprave za razvoj socijalne ekonomije i zadrugarstva na višu hijerarhijsku razinu u nekom od relevantnih ministarstava mogla bi odaslati ne samo 'pozitivnu poruku' nego olakšati razvojne iskorake u ovom području u Hrvatskoj.

\subsection{Stanje zadružnog sektora u Europskoj uniji}

Prema podacima Europske komisije, danas u Europskoj uniji posluje otprilike 250.000 zadruga sa 163 milijuna zadrugara (svaki treći građanin EU-a) i zapošljavaju otprilike $\mathbf{5 , 4}$ milijuna ljudi ${ }^{3}$. Prema istraživanju (Cooperatives Europe,

3 Dostupno na http://ec.europa.eu/enterprise/policies/sme/promoting-entrepreneurship/ social-economy/co-operatives/index_en.htm 
2010.) koje je provelo udruženje Cooperatives Europe Asbl. ${ }^{4}$ u 2010. godini na temelju podataka svojih članica iz 2009. godine, najviše zadruga registrirano je u Italiji, za kojom slijede Španjolska i Francuska. U tablicama 4 i 5 dan je pregled broja registriranih zadruga (članica Cooperatives Europe) u zemljama članicama Europske unije i drugim promatranim zemljama5.

Tablica 1.

Zadruge u zemljama članicama Europske unije

\begin{tabular}{|c|c|c|c|}
\hline Zemlja & Zadruge & Članovi & Zaposleni \\
\hline Austrija & 2.339 & 4.866 .148 & 105.989 \\
\hline Belgija & 166 & 2.670 .000 & 13.547 \\
\hline Bugarska & 1.273 & 179.309 & 26.386 \\
\hline Cipar & 620 & 1.275 .993 & 5.067 \\
\hline Češka & 1.395 & 897.899 & 71.939 \\
\hline Njemačka & 7.415 & 20.509 .973 & 830.258 \\
\hline Danska & 523 & 1.840 .803 & 70.757 \\
\hline Estonija & 1.604 & 410.000 & 4.800 \\
\hline Španjolska & 24.276 & 6.960 .870 & 384.398 \\
\hline Finska & 380 & 3.164 .226 & 69.953 \\
\hline Francuska & 21.000 & 23.000 .000 & 900.000 \\
\hline Grčka & 6.392 & 942.991 & 12.538 \\
\hline Mađarska & 2.769 & 547.000 & 85.682 \\
\hline Irska & 183 & 152.000 & 18.869 \\
\hline Italija & 41.552 & 13.063 .419 & 1.146 .950 \\
\hline Luksemburg & 18 & 5.203 & 476 \\
\hline Litva & 490 & 221.858 & 8.971 \\
\hline Letonija & 74 & 17.330 & 440 \\
\hline Malta & 58 & 5.663 & 250 \\
\hline Nizozemska & 677 & 3.249 .000 & 184.053 \\
\hline
\end{tabular}

4 Cooperatives Europe Asbl (2010.), "European Co-operatives Key Statistics 2009”, dostupno na http://www.coopseurope.coop

5 Rezultati ovog istraživanja odnose se samo na zadruge članice Cooperatives Europe Asbl. te da u istraživanje nisu uključeni francuske školske zadruge (njih 50.000 sa 5 milijuna članova), kao niti zadruge iz sektora osiguranja, koje su istupile iz Cooperatives Europe 2007. godine. 


\begin{tabular}{|l|c|c|c|}
\hline Zemlja & Zadruge & Članovi & Zaposleni \\
\hline Poljska & 8.823 & 8.000 .000 & 400.000 \\
\hline Portugal & 2.946 & 2.135 .000 & 47.000 \\
\hline Rumunjska & 1.577 & 809.170 & 34.313 \\
\hline Švedska & 9.170 & 4.069 .852 & 140.520 \\
\hline Slovenija & 77 & 16.903 & 3.428 \\
\hline Slovačka & 383 & 570.845 & 129.130 \\
\hline Ujedinjeno Kraljevstvo & 977 & 8.434 .538 & $\mathbf{4 . 7 2 2 . 0 4 8}$ \\
\hline Ukupno EU27 & $\mathbf{1 3 7 . 1 5 7}$ & $\mathbf{1 0 8 . 0 1 5 . 9 9 3}$ & \\
\hline
\end{tabular}

Izvor: Cooperatives Europe Asbl (2010.), “European Co-operatives Key Statistics 2009.", dostupno na http://www. coopseurope.coop

U zemljama Europske unije registrirano je ukupno 137.157 zadruga članica Cooperatives Europe Asbl., koje broje više od 108 milijuna članova i zapošljavaju gotovo 5 milijuna ljudi.

Tablica 2.

Zadruge u ostalim promatranim zemljama Europe

\begin{tabular}{|l|c|c|c|}
\hline Zemlja & Zadruge & Članovi & Zaposleni \\
\hline Rusija & 3.163 & 4.407 .930 & 285.155 \\
\hline Bjelorusija & 126 & 1.300 .000 & 99.399 \\
\hline Hrvatska & 1.428 & 23.051 & N.A \\
\hline Gruzija & N.A & N.A & 9.193 \\
\hline Moldavija & 134 & 340.000 & 42.510 \\
\hline Norveška & 5.348 & 2.040 .000 & 6.500 \\
\hline Srbija & 1.403 & 176.069 & 84.104 \\
\hline Švicarska & 1.416 & 3.426 .151 & 39.582 \\
\hline Turska & 2.343 & 2.621 .416 & 64.900 \\
\hline Ukrajina & 5.088 & 507.800 & $\mathbf{6 3 5 . 1 9 8}$ \\
\hline Ukupno & $\mathbf{2 0 . 4 4 9}$ & $\mathbf{1 4 . 8 4 2 . 4 1 7}$ & \\
\hline
\end{tabular}

Izvor: Cooperatives Europe Asbl (2010.), “European Co-operatives Key Statistics 2009.”, dostupno na http://www. coopseurope.coop

U ostalim promatranim zemljama Europe (uključujući Rusiju i Tursku) evidentirano je 20.499 zadruga sa gotovo 15 milijuna članova i 635.198 zaposlenih. 
Zbrojimo li podatke u tablicama 4 i 5, doći ćemo do podatka da u promatranim zemljama EU regije posluje 157.606 zadruga sa 122.858.410 članova, u kojima je zaposleno čak 5.357.246 zaposlenih.

Promatramo li broj članova zadruga u usporedbi sa brojem stanovnika pojedine promatrane zemlje, dobit ćemo rezultate prikazane na Slici 1.

Slika 1.

Odnos članova zadruga prema broju stanovnika

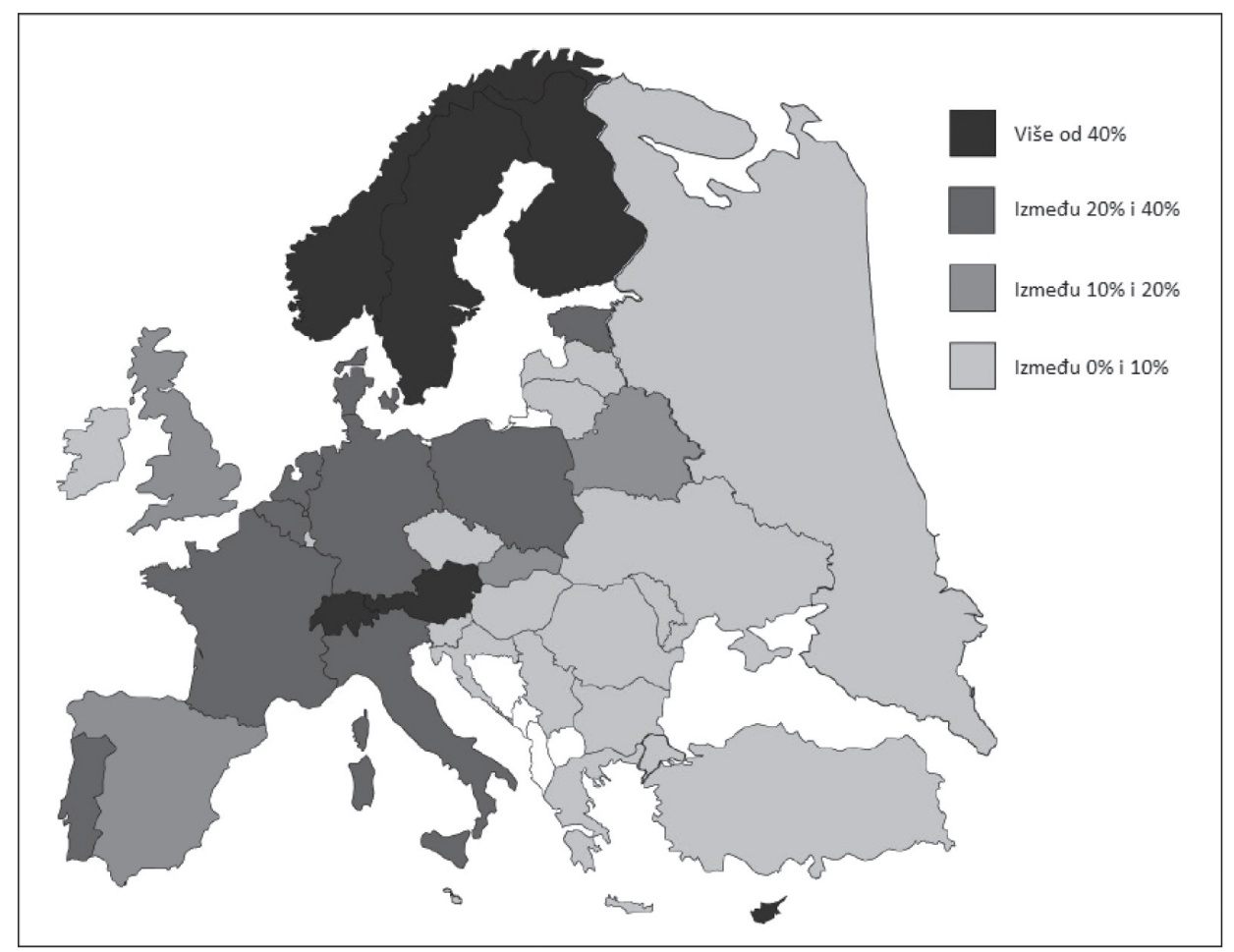

Izvor: Cooperatives Europe Asbl (2010.), "European Co-operatives Key Statistics 2009.", dostupno na http://www. coopseurope.coop 
Slika 2.

Zaposleni u zadrugama u zemljama članicama Europske unije

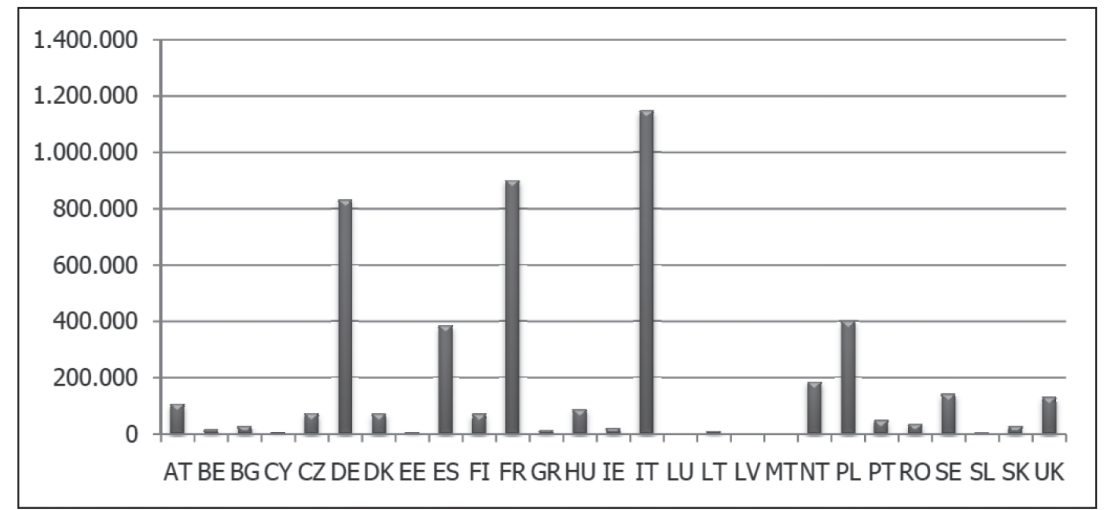

Izvor: Cooperatives Europe Asbl (2010.), "Europen Co-operatives Key Statistics 2009.", dostupno na http://www. coopseurope.coop

Slika 3.

Zaposleni u zadrugama u ostalim zemljama Europe

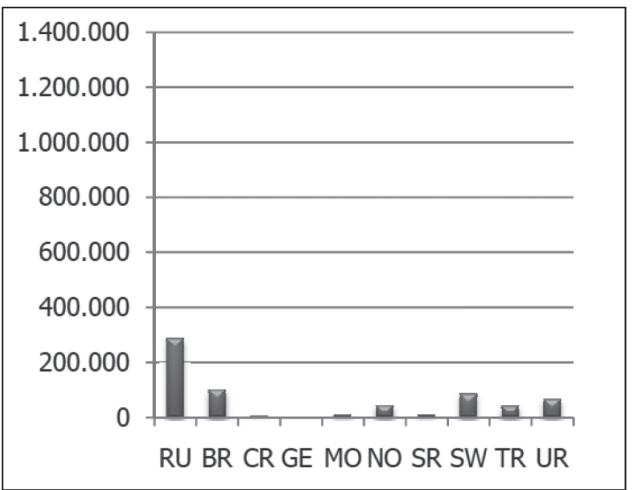

Izvor: Cooperatives Europe Asbl (2010.), "European Co-operatives Key Statistics 2009.", dostupno na http://www. coopseurope.coop

Kako je prikazano na slikama 2 i 3, najviše zaposlenih u zadrugama ima u Italiji, Francuskoj i Njemačkoj, dok važnu poziciju u broju zaposlenih zadruge imaju i u Poljskoj te Španjolskoj.

Odnos između aktivnog stanovništva i zaposlenih u zadrugama po zemljama također daje zanimljive podatke, kao što je prikazano na Slici 4. 
Slika 4.

Zaposleni u zadrugama / ukupno aktivno stanovništvo u zemljama Europske unije

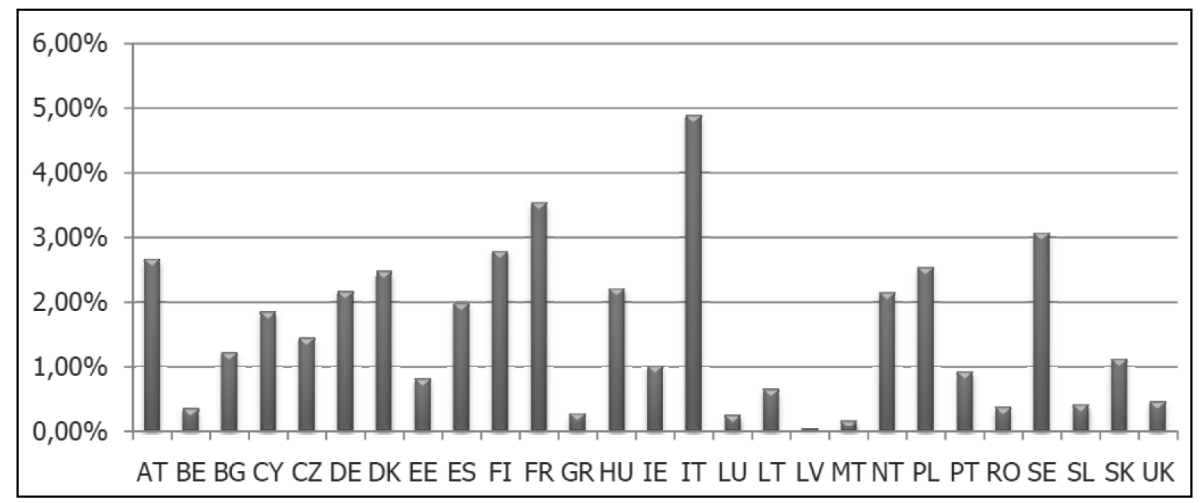

Izvor: Cooperatives Europe Asbl (2010.), “Europen Co-operatives Key Statistics 2009.”, dostupno na http://www. coopseurope.coop

Zaposleni u zadrugama u odnosu na ukupno aktivno stanovništvo u Italiji iznosi gotovo 5\%, što je zasigurno najveći udio zaposlenih u zadrugama u ukupnom aktivnom stanovništvu u cijeloj Europskoj uniji. Za Italijom slijede Francuska i Švedska, dok je u ostalim članicama Europske unije taj udio manji od 3\%.

Slika 5.

Zadružna poduzeća prema sektorima

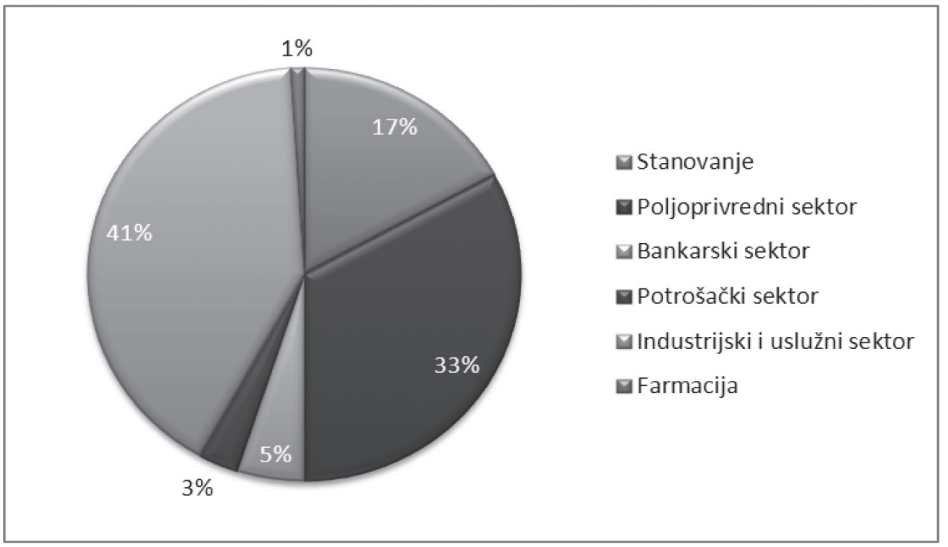

Izvor: Cooperatives Europe Asbl (2010.), "European Co-operatives Key Statistics 2009.", dostupno na http://www. coopseurope.coop

Promatramo li podatke prema sektorima poslovanja zadružnih poduzeća (Slika 5), možemo zaključiti da ih najviše pripada poljoprivrednom sektoru te industrijskom i uslužnom sektoru. Većina zadruga u industrijskom i uslužnom sektoru su male i, 
u nekim zemljama poput Španjolske i Italije, vrlo brojne. Poljoprivredne zadruge vrlo su proširene u zemljama sjeverozapadne Europe.

Slika 6.

Zadružni članovi prema sektorima

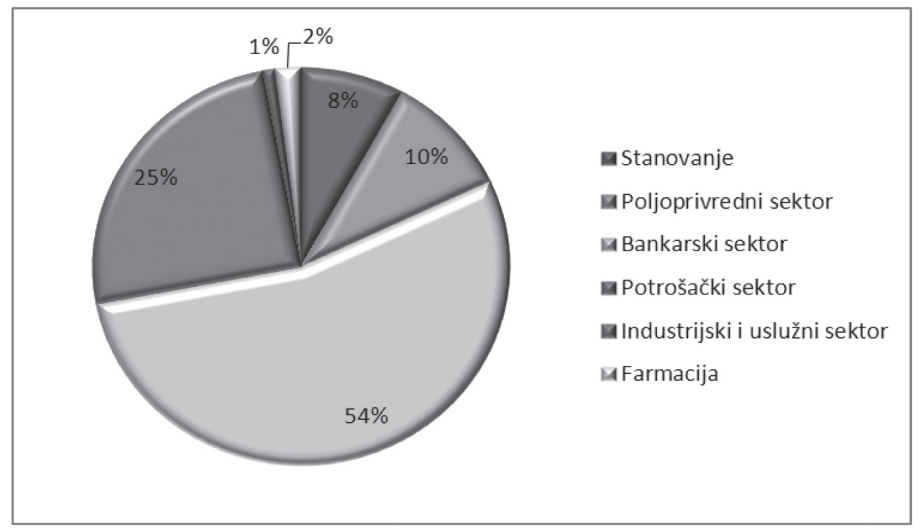

Izvor: Cooperatives Europe Asbl (2010.), "European Co-operatives Key Statistics 2009”, dostupno na http://www. coopseurope.coop

Većina zadružnih članova posluje u bankarskom i potrošačkom sektoru (Slika 6), ponajviše zbog specifičnosti njihovih aktivnosti. U bankarskom sektoru većina klijenata su također i članovi zadruge. Potrošačke zadruge se pak, po samoj prirodi, temelje na svojim članovima. Procjenjuje se da su podaci vezani uz sektor stanovanja zapravo veći nego je prikazano, zbog nedostatka relevantnih podataka.

Slika 7.

Zaposleni u zadrugama prema sektoru

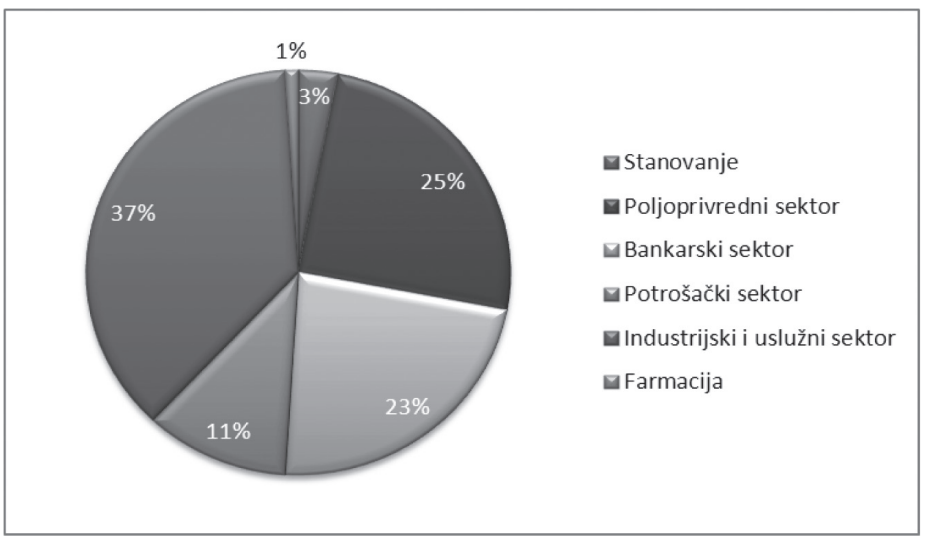

Izvor: Cooperatives Europe Asbl (2010.), “European Co-operatives Key Statistics 2009.”, dostupno na http://www. coopseurope.coop 
Promatramo li zaposlene u zadrugama prema sektorima poslovanja zadruga (Slika 7), možemo zaključiti da je najviše zaposlenih u industrijskom i uslužnom sektoru, za kojim slijede poljoprivredni i bankarski sektori. U sektoru stanovanja broj zaposlenih je relativno nizak s obzirom na velik broj poduzeća i članova, što je vjerojatno posljedica izravnog uključivanja članova zadruge u aktivnosti potrebne za upravljanje zadrugom.

\subsection{Trendovi zadružnog sektora u europskim zemljama}

Zadruge imaju značajnu ulogu u današnjem europskom gospodarstvu, što dokazuju impresivne brojke iznesene u prethodnim poglavljima. Današnje su zadruge suočene s mnogim izazovima i moraju se odlučiti hoće li svoj razvoj temeljiti slijedeći trendove prema restrukturiranju u manje poslovne jedinice ili pak prema strateškoj diverzifikaciji, gradeći poslovanje na alternativnim zadružnim poslovnim politikama, suradnji unutar integriranih sustava i strateških mreža te upravljanjem na temelju vrijednosti.

S obzirom na različitosti zadruga u Europi, teško je izdvojiti trendove koji se odnose na sve zadruge u svim zemljama. Prema istraživanju Muenknera (2003.) trendove je moguće identificirati:

- prema poslovnim aktivnostima zadruge i vrsti strukture, i

- prema ciljevima i poslovnoj strategiji zadruga.

Prema poslovnim aktivnostima, zadruge možemo podijeliti na dvije osnovne skupine:

- Zadruge potrošača (uključujući potrošačke zadruge, ne-specijalizirane zadružne banke, stambene zadruge, uslužne zadruge) koje možemo nazvati "otvorenim zadrugama” i čija je osnovna karakteristika da svaki potrošač može postati članom zadruge, i

- Zadruge proizvođača i poduzetnika (uključujući obrtničke zadruge, maloprodajne zadruge, zadruge malih i srednjih poduzetnika, specijalizirane zadružne banke) koje možemo nazvati "zatvorenim zadrugama" i čija je osnovna karakteristika da samo pripadnici određene profesije mogu postati članovima.

Otvorene zadruge pokazale su tendenciju rasta spajanjima i preuzimanjima. Mnoge takve zadruge postale su velike organizacije koje podsjećaju na kompanije, okrenute ostvarivanju dobiti i neograničenom poslovanju s ne-članovima, što dodatno slabi odnose između članova. Otvorene zadruge također karakterizira trend "demutualizacije": bez učinkovite kontrole članova, stvaraju se rezerve akumulirane iz zadržane dobiti generacija članova, koje se mogu iskoristiti za financiranje rasta i troškova poslovanja zadruge ili se, u slučaju pretvaranja zadruge u trgovačko društvo, pretvaraju u kapital. 
Zatvorene zadruge uključuju i poljoprivredne zadruge, zanatske zadruge, zadruge neovisnih poduzetnika i pružatelja usluga, kojima zadruga predstavlja nezamjenjivog poslovnog partnera. U doba sve kompliciranije proizvodnje i marketinških procesa te upotrebe skupe moderne tehnologije, odnosi između zadruge i poslovanja njenih članova postaju sve bliskiji. Javlja se sve veća potreba za planiranjem poslovanja i savjetovanjem, kao i outsourcingom određenih aktivnosti sa članova u zadrugu, što vodi do stvaranja tzv. "integriranih zadruga", gdje poslovne aktivnosti članova postaju produžetkom poslovnih aktivnosti zadruge i obrnuto.

Promatrano prema ciljevima i poslovnoj strategiji zadruga, možemo identificirati pet osnovnih trendova u razvoju zadruga:

1. približavanje poslovanja zadruge principima poslovanja trgovačkih društava, što je posebno naglašeno u zadrugama koje posluju u uvjetima izražene konkurencije;

2. pojava gospodarskih zadruga kao čistih tržišnih struktura, orijentiranih na korisnike, ali bez upravljanja temeljenog na zadružnim vrijednostima (radne skupine, konzorciji, strateške mreže i slično);

3. razvoj suradnje temeljene na zadružnim vrijednostima i načelima;

4. orijentacija prema socijalnoj ekonomiji (zajedno sa udrugama i zakladama), u cilju pronalaženja alternativnih ili suplementarnih rješenja sustavu tržišne ekonomije;

5. pojava zadruga sa socijalnim karakterom koje postaju integralnim dijelom neprofitnog sektora.

Promatramo li pak zadružni pokret u cjelini, Međunarodna organizacija rada prema rezultatima istraživanja (Vanhuynegem, 2008.) izdvaja osam najvažnijih trendova zadružnog pokreta današnjice:

- kontinuirano revidiranje i usklađivanje zadružnih politika i zakona

- usklađivanje zadružnih podzakonskih akata sa revidiranim politikama i zakonima

- prilagodba i repozicioniranje zadruga kako bi se mogle nositi sa postojećim tržišnim uvjetima

- Zadruge postaju poduzetnički orijentirane te mijenjaju tradicionalno, neprofitno poslovanje na poslovanje s većim tržišnim fokusom

- diverzifikacija zadruga, često uslugama koje se međusobno nadopunjuju (na primjer poljoprivredni proizvodi/marketing, štednja, kreditiranje ili bankarske usluge)

- $\quad$ preraspodjela odgovornosti za razvoj zadruga sa vlade i njenih tijela na autonomne organizacije za razvoj zadruga

- obnovljen interes za zadruge i zadrugarstvo, zahvaljujući međunarodnim agencijama za razvoj zadruga 
- osnaživanje zadružnih obrazovnih institucija u namjeri da se osigura potrebno znanje i vještine potrebne za poslovanje u konkurentnom okružju. Jedan od vjerojatno najvažnijih trendova u današnjem zadrugarstvu jest činjenica da posljednjih godina organizacijski oblik zadruge ima sve veću ulogu u djelatnostima općeg interesa kao što su obrazovanje, promet $i$ energija. Novi oblik zadruga koje su po svojoj prirodi okrenute lokalnoj zajednici sve više se ističu zbog svog doprinosa različitim rizičnim skupinama i zajednici u cjelini. Interes za razvoj zadruga u socijalno orijentirane modele proizlazi iz snažne povezanosti sa razvojem tradicionalnih modela socijalne skrbi prema modelu "socijalne zajednice". Ovaj razvoj zadruga posebno je interesantan za zemlje u tranziciji iz dva razloga: razvoj poduzetničkog gospodarstva $i$ zadružnog sustava te razvoja novog sustava socijalne skrbi. Među novim rješenjima posebno se ističe "bottom-up" ponuda usluga socijalne skrbi u zajednici kroz model samopomoći. U ovom slučaju zadružni model predstavlja efikasno sredstvo za ubrzanje tranzicije i rješavanje brojnih problema, kao što su niska potražnja za radnom snagom i siromaštvo, kao i pružanje novih rješenja za borbu s rastućim socijalnim problemima.

\section{Stanje i trendovi u zadrugarstvu u Hrvatskoj}

Poslovanje zadruga u Republici Hrvatskoj može se pratiti kroz nekoliko bitnih segmenata poslovanja kao što je veličina aktive, ostvareni prihodi i rashodi te dobit ili gubitak. Osim navedenih kao bitan element navodi se i broj zaposlenih. Proučavajući navedene pozicije moguće je izvući određene konkretne zaključke o financijskom položaju i uspješnosti poslovanja zadruga.

Prema podacima Hrvatskog saveza zadruga na dan 17. prosinca 2010. godine u Republici Hrvatskoj je bilo aktivno ukupno 1.691 zadruga. U Republici Hrvatskoj je u 2009. godini djelovalo 1.125 zadruga koje su Financijskoj agenciji (FINA) predale završne izvještaje.

U Republici Hrvatskoj prosječno po županiji djeluje 53,57 zadruga. Koprivničkokriževačka, Osječko-baranjska, Splitsko-dalmatinska županija i Grad Zagreb imaju iznadprosječan broj zadruga, odnosno više od 80 zadruga po županiji. Za razliku od njih, Ličko-senjska, Međimurska i Krapinsko-zagorska županija imaju značajno negativno odstupanje od prosjeka s manje od 30 zadruga po županiji. Po broju zadruga prednjači Koprivničko-križevačka županija, u kojoj je 2009. djelovalo 130 zadruga, odnosno 11,56\% svih zadruga u Republici Hrvatskoj. U toj županiji polovicu zadruga (65) čine uslužne zadruge. U Požeško-slavonskoj županiji registrirano je svega 15 zadruga što je udio od 1,33\% ukupnog broja zadruga. Pritom najveći udio (80\%) imaju poljoprivredne zadruge. 
Tablica 3.

Broj zadruga koje su predale završni račun za 2009. godinu.

\begin{tabular}{|c|c|c|c|c|c|c|c|}
\hline $\begin{array}{l}\text { Red. } \\
\text { br. }\end{array}$ & Županija & $\begin{array}{l}\text { Obrtničke } \\
\text { zadruge }\end{array}$ & $\begin{array}{c}\text { Poljoprivredne } \\
\text { zadruge }\end{array}$ & $\begin{array}{c}\text { Stambene } \\
\text { zadruge }\end{array}$ & $\begin{array}{l}\text { Štedno- } \\
\text { kreditne } \\
\text { zadruge }^{6}\end{array}$ & $\begin{array}{l}\text { Uslužne } \\
\text { zadruge }\end{array}$ & Ukupno \\
\hline 1. & Zagrebačka & 5 & 33 & 2 & 2 & 7 & 49 \\
\hline 2. & Krapinsko-zagorska & 3 & 24 & 0 & 0 & 0 & 27 \\
\hline 3. & Sisačko-moslavačka & 2 & 34 & 0 & 0 & 7 & 43 \\
\hline 4. & Karlovačka & 3 & 28 & 2 & 2 & 8 & 43 \\
\hline 5. & Varaždinska & 1 & 22 & 3 & 6 & 6 & 38 \\
\hline 6. & Koprivničko-križevačka & 28 & 25 & 10 & 2 & 65 & 130 \\
\hline 7. & Bjelovarsko-bilogorska & 2 & 47 & 1 & 0 & 30 & 80 \\
\hline 8. & Primorsko-goranska & 7 & 32 & 0 & 1 & 6 & 46 \\
\hline 9. & Ličko-senjska & 0 & 13 & 0 & 0 & 3 & 16 \\
\hline 10. & Virovitičko-podravska & 7 & 33 & 1 & 3 & 4 & 48 \\
\hline 11. & Požeško-slavonska & 1 & 12 & 0 & 0 & 2 & 15 \\
\hline 12. & Brodsko-posavska & 2 & 23 & 0 & 2 & 3 & 30 \\
\hline 13. & Zadarska & 7 & 45 & 0 & 0 & 6 & 58 \\
\hline 14. & Osječko-baranjska & 5 & 65 & 1 & 5 & 17 & 93 \\
\hline 15. & Šibensko-kninska & 4 & 48 & 2 & 0 & 11 & 65 \\
\hline 16. & Vukovarsko-srijemska & 5 & 49 & 2 & 3 & 8 & 67 \\
\hline 17. & Splitsko-dalmatinska & 7 & 65 & 6 & 1 & 13 & 92 \\
\hline 18. & Istarska & 2 & 20 & 5 & 2 & 3 & 32 \\
\hline 19. & Dubrovačko-neretvanska & 0 & 35 & 1 & 0 & 5 & 41 \\
\hline 20. & Međimurska & 3 & 10 & 1 & 5 & 4 & 23 \\
\hline 21. & Grad Zagreb & 14 & 16 & 11 & 24 & 24 & 89 \\
\hline & Ukupno & 108 & 679 & 48 & 58 & 232 & 1.125 \\
\hline
\end{tabular}

Izvor: Hrvatski savez zadruga

Najveći broj zadruga u 2009. godini činile su poljoprivredne zadruge s udjelom od 60,36\% u ukupnom broju zadruga. Slijede ih uslužne (20,62\%) i obrtničke (9,60\%) zadruge, dok je najmanje bilo štedno-kreditnih $(5,16 \%)$ i stambenih zadruga, koje su činile svega 4,27\% od ukupnog broja zadruga. U Hrvatskoj djeluje 679 poljopri-

6 Zakonom iz 2006. godine štedno-kreditne zadruge su trebale svoje poslovanje preustrojiti u skladu sa odredbama Zakona o kreditnim unijama (NN 141, 2006.). Tek 20 štedno-kreditnih zadruga se uspješno preustrojilo u kreditne unije u skladu s novim zakonskim propisom, dok su ostale u procesu likvidacije. 
vrednih zadruga. Pritom prednjače Osječko-baranjska i Splitsko-dalmatinska županija - svaka s po 65 registriranih poljoprivrednih zadruga.

\subsection{Analiza kretanje temeljnih financijskih pokazatelja zadružnog sektora $u$ Hrvatskoj}

Ukupno promatrano, zadruge su u 2005. i 2006. ostvarile veće gubitke od dobitaka, međutim do promjene dolazi u 2007. godini kada ostvareni dobici značajno nadmašuju ostvarene gubitke. Iako se ta razlika u sljedećim godinama smanjuje zbog smanjenja dobiti, ostvareni dobitak je još uvijek veći od ostvarenog gubitka, odnosno ukupni financijski rezultat zadruga je pozitivan.

Slika 8.

Kretanje dobiti i gubitka zadruga u Hrvatskoj, 2005. - 2009.

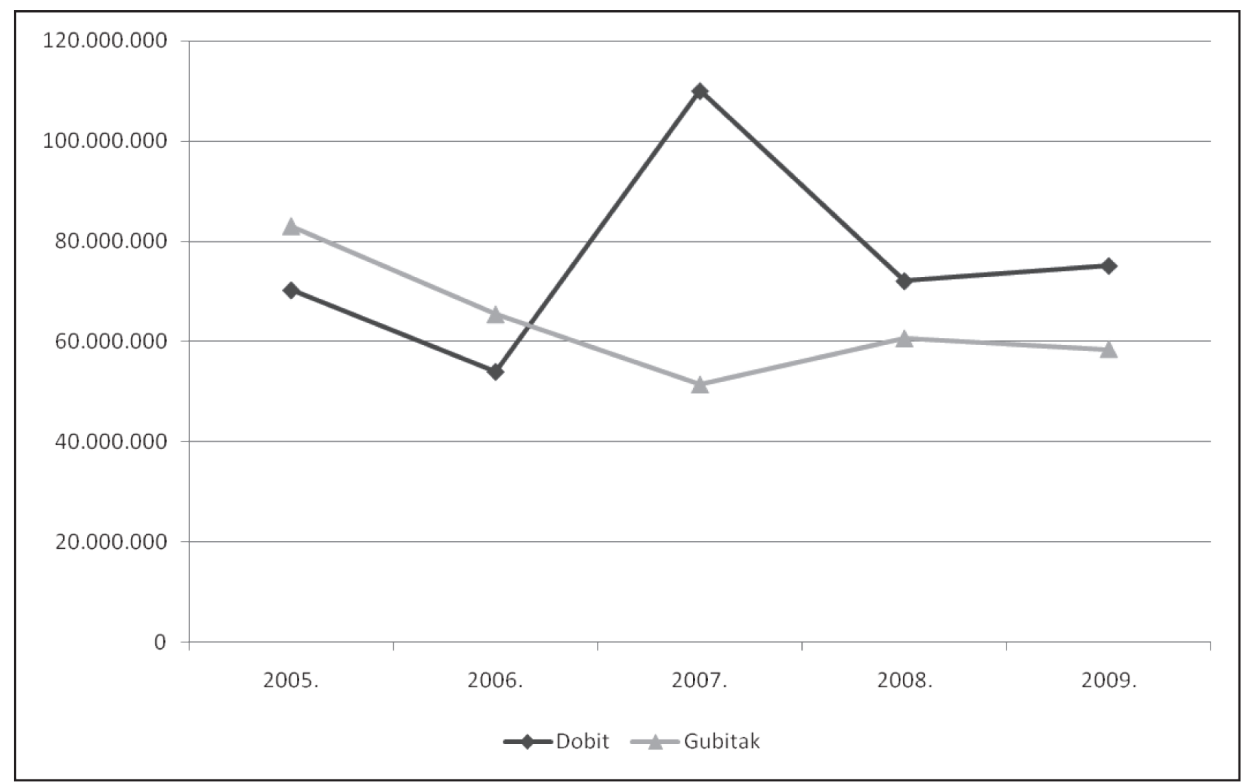

Izvor: Hrvatski savez zadruga

Ekonomičnost poslovanja pokazuje odnos prihoda i rashoda ostvarenih tijekom obračunskog razdoblja, pokazuju koliko se prihoda ostvari po jedinici rashoda. Osim pokazatelja ukupne ekonomičnosti postoje i parcijalni pokazatelji ekonomičnosti koji uključuju udio prihoda u odnosu na pripadajuće rashode. Osnovni kriterij ovog pokazatelja je da je veći od 1, odnosno da su prihodi veći od rashoda što znači da zadruga ostvaruje dobit, odnosno uspješno posluje. 
U svim analiziranim godinama pokazatelj ekonomičnosti je veći od jedan, što znači da zadruge uspijevaju generirati veće prihode od rashoda. Većina županija u 2009. godini ostvarila je ekonomičnost veću od jedan. Najmanju ekonomičnost u 2009. godini ostvarila je Zadarska županija $(0,931$, što znači da su rashodi bili za 0,069\% veći od prihoda). Najbolji pokazatelj ekonomičnosti u 2009. godini ostvarila je Požeško-slavonska županija $(1,721)$.

Tablica 4.

Ekonomičnost poslovanja zadruga po županijama, 2005. - 2009.

\begin{tabular}{|c|c|c|c|c|c|c|}
\hline & \multirow{2}{*}{ ŽUPANIJA } & \multicolumn{5}{|c|}{ EKONOMIČNOST POSLOVANJA } \\
\hline & & 2005. & 2006. & 2007. & 2008. & 2009. \\
\hline 1. & Zagrebačka & 0,942 & 1,616 & 1,007 & 0,939 & 0,942 \\
\hline 2. & Krapinsko-zagorska & 0,904 & 0,996 & 1,019 & 1,000 & 0,986 \\
\hline 3. & Sisačko-moslavačka & 1,009 & 1,012 & 1,018 & 1,008 & 1,005 \\
\hline 4. & Karlovačka & 0,994 & 0,982 & 0,967 & 0,932 & 0,964 \\
\hline 5. & Varaždinska & 1,003 & 1,003 & 1,005 & 0,862 & 1,064 \\
\hline 6. & Koprivničko-križevačka & 0,991 & 0,999 & 1,011 & 0,993 & 0,968 \\
\hline 7. & Bjelovarsko-bilogorska & 0,999 & 1,058 & 1,001 & 1,009 & 1,008 \\
\hline 8. & Primorsko-goranska & 1,066 & 0,996 & 1,036 & 1,017 & 1,008 \\
\hline 9. & Ličko-senjska & 0,995 & 0,965 & 1,028 & 1,074 & 1,042 \\
\hline 10. & Virovitičko-podravska & 0,885 & 0,912 & 0,985 & 1,004 & 0,978 \\
\hline 11. & Požeško-slavonska & 0,960 & 0,775 & 1,013 & 0,993 & 1,721 \\
\hline 12. & Brodsko-posavska & 1,007 & 1,004 & 1,006 & 1,017 & 1,006 \\
\hline 13. & Zadarska & 0,877 & 0,903 & 0,818 & 0,887 & 0,931 \\
\hline 14. & Osječko-baranjska & 1,011 & 1,007 & 1,066 & 1,025 & 1,019 \\
\hline 15. & Šibensko-kninska & 0,996 & 1,000 & 0,983 & 1,002 & 1,013 \\
\hline 16. & Vukovarsko srijemska & 1,128 & 1,024 & 1,041 & 1,033 & 1,014 \\
\hline 17. & Splitsko-dalmatinska & 1,020 & 1,014 & 1,021 & 1,028 & 1,008 \\
\hline 18. & Istarska & 1,009 & 1,005 & 1,018 & 1,004 & 1,011 \\
\hline 19. & Dubrovačko neretvanska & 1,023 & 0,966 & 0,975 & 0,939 & 0,958 \\
\hline 20. & Međimurska & 1,004 & 1,001 & 1,010 & 0,995 & 0,969 \\
\hline \multirow[t]{2}{*}{21.} & Grad Zagreb & 1,058 & 1,031 & 1,074 & 1,055 & 1,063 \\
\hline & Ukupno RH & 1,007 & 1,005 & 1,022 & 1,004 & 1,007 \\
\hline
\end{tabular}

Izvor: Hrvatski savez zadruga 
Ukupno gledano, zadruge imaju relativno nisku, ali pozitivnu ekonomičnost. Međutim, u poslovanju zadruga primarni cilj nije ostvarivanje profita pa i njihovo poslovanje treba promatrati na složeniji način. Jedan od temeljnih pokazatelja financijske uspješnosti i profitabilnosti je rentabilnost imovine (omjer neto dobiti i ukupnih prihoda)

U 2009. godini najbolju rentabilnost imovine ostvaruje sektor uslužnih zadruga sa $12,75 \%$. Najslabiji sektor u postizanju većih stopa povrata na imovinu su obrtničke zadruge koje su u 2009. godini ostvarile povrat od svega 0,29\%.

Tablica 5.

Rentabilnost imovine zadruga po sektorima, 2005. - 2009.

\begin{tabular}{|c|l|c|c|c|c|c|}
\hline \multirow{2}{*}{} & \multirow{2}{*}{ SEKTOR } & \multicolumn{5}{c|}{ RENTABILNOST IMOVINE } \\
\cline { 3 - 7 } & & $\mathbf{2 0 0 5}$ & $\mathbf{2 0 0 6}$ & $\mathbf{2 0 0 7 .}$ & $\mathbf{2 0 0 8 .}$ & $\mathbf{2 0 0 9 .}$ \\
\hline 1. & Poljoprivredne zadruge & $1,80 \%$ & $1,21 \%$ & $2,61 \%$ & $1,77 \%$ & $1,31 \%$ \\
\hline 2. & Obrtničke zadruge & $3,96 \%$ & $1,59 \%$ & $1,65 \%$ & $0,80 \%$ & $0,29 \%$ \\
\hline 3. & Uslužne zadruge & $3,45 \%$ & $3,68 \%$ & $8,46 \%$ & $5,58 \%$ & $12,75 \%$ \\
\hline 4. & Stambene zadruge & $7,55 \%$ & $5,36 \%$ & $3,55 \%$ & $1,31 \%$ & $0,89 \%$ \\
\hline 5. & Štedno-kreditne zadruge & $1,12 \%$ & $1,04 \%$ & $1,16 \%$ & $2,08 \%$ & $3,75 \%$ \\
\hline & SVEUKUPNO RH & $\mathbf{1 , 8 4} \%$ & $\mathbf{1 , 3 4} \%$ & $\mathbf{2 , 2 1} \%$ & $\mathbf{1 , 7 0} \%$ & $\mathbf{1 , 7 8} \%$ \\
\hline
\end{tabular}

Izvor: Hrvatski savez zadruga

\subsection{Kretanje broja zaposlenih u zadrugama u Republici Hrvatskoj}

U Hrvatskoj je u 2009. godini djelovalo ukupno 1.125 zadruga koje su imale nešto više od 23.000 članova i 3.565 zaposlenih. Na temelju raspoloživih podataka o zaposlenima u zadrugama u 2007., 2008. i 2009. godini moguće je donijeti zaključke o doprinosu zadruga zaposlenosti. Iako kroz analizirana razdoblja nema značajnih promjena u broju zaposlenih po zadrugama, generalni trend je smanjivanje broja zaposlenih. Od 2007. godine do 2009. godine broj zaposlenih po zadrugama u Republici Hrvatskoj prosječno se godišnje smanjivao za 6,60\%. Najveći broj zaposlenih u zadrugama u 2009. godini ima Osječko-baranjska županija s ukupno 431 zaposlenim. Iako Koprivničko-križevačka županija ima najveći broj registriranih zadruga, ona ima zaposleno 403 djelatnika, odnosno prosječno tri djelatnika po jednoj zadruzi. 
Tablica 6.

Broj zaposlenih u zadrugama po županijama, 2005. - 2009.

\begin{tabular}{|c|c|c|c|c|}
\hline & \multirow{2}{*}{ ŽUPANIJA } & \multicolumn{3}{|c|}{ ZAPOSLENI } \\
\hline & & 2007. & 2008. & 2009. \\
\hline 1. & Zagrebačka & 69 & 36 & 33 \\
\hline 2. & Krapinsko-zagorska & 314 & 286 & 274 \\
\hline 3. & Sisačko-moslavačka & 62 & 51 & 56 \\
\hline 4. & Karlovačka & 69 & 99 & 96 \\
\hline 5. & Varaždinska & 104 & 75 & 57 \\
\hline 6. & Koprivničko-križevačka & 500 & 382 & 403 \\
\hline 7. & Bjelovarsko-bilogorska & 122 & 108 & 126 \\
\hline 8. & Primorsko-goranska & 128 & 132 & 138 \\
\hline 9. & Ličko-senjska & 19 & 15 & 23 \\
\hline 10. & Virovitičko-podravska & 297 & 305 & 296 \\
\hline 11. & Požeško-slavonska & 21 & 23 & 18 \\
\hline 12. & Brodsko-posavska & 211 & 157 & 168 \\
\hline 13. & Zadarska & 217 & 171 & 160 \\
\hline 14. & Osječko-baranjska & 436 & 453 & 431 \\
\hline 15. & Šibensko-kninska & 147 & 146 & 138 \\
\hline 16. & Vukovarsko srijemskaM & 407 & 336 & 322 \\
\hline 17. & Splitsko-dalmatinska & 280 & 304 & 309 \\
\hline 18. & Istarska & 67 & 57 & 66 \\
\hline 19. & Dubrovačko neretvanska & 137 & 124 & 123 \\
\hline 20. & Medimurska & 121 & 123 & 144 \\
\hline \multirow[t]{2}{*}{21.} & Grad Zagreb & 359 & 208 & 184 \\
\hline & Ukupno RH & 4.087 & 3.591 & 3.565 \\
\hline
\end{tabular}

Izvor: Hrvatski savez zadruga

Tablica 7.

Broj zaposlenih u zadrugama po sektorima, 2005. - 2009.

\begin{tabular}{|c|l|r|r|r|}
\hline \multirow{2}{*}{} & & \multicolumn{3}{c|}{ ZAPOSLENI } \\
\cline { 3 - 5 } & & $\mathbf{2 0 0 7}$ & $\mathbf{2 0 0 8 .}$ & $\mathbf{2 0 0 9 .}$ \\
\hline 1. & Poljoprivredne zadruge & 2.828 & 2.754 & 2.737 \\
\hline 2. & Obrtničke zadruge & 294 & 258 & 260 \\
\hline 3. & Uslužne zadruge & 385 & 301 & 354 \\
\hline 4. & Stambene zadruge & 185 & 140 & 109 \\
\hline 5. & Štedno-kreditne zadruge & 395 & 138 & 105 \\
\hline & SVEUKUPNO RH & $\mathbf{4 . 0 8 7}$ & $\mathbf{3 . 5 9 1}$ & $\mathbf{3 . 5 6 5}$ \\
\hline
\end{tabular}

Izvor: Hrvatski savez zadruga 
Najveći broj zaposlenih imaju poljoprivredne zadruge koje su istovremeno najbrojnije. Poljoprivredne zadruge u 2009. godini imaju ukupno 2.737 zaposlenih, što je 60,36\% ukupno zaposlenih u zadružnom sektoru. Poljoprivredne zadruge imaju prosječno četiri zaposlena djelatnika po jednoj zadruzi.

\subsection{Doprinos zadrugarstva hrvatskom gospodarstvu}

Tijekom devedesetih nekada vrlo popularan oblik udruživanja u obliku zadruga postaje potiskivan zbog vezivanja zadrugarstva uz socijalistički sustav. (Bateman i Maleković, 2003.:20) Zakon o zadrugama donesen je tek 1995. godine. Razvijaju se i poticajni mehanizmi koji podupiru osnivanje i djelovanje zadruga. No veći zamah u formiranju novih zadruga i poslovnoj aktivnosti postojećih još uvijek nije nastupio. Prevladavaju niska efikasnost i spor razvoj, što rezultira relativno malim doprinosom i malim utjecajem zadruga u gospodarstvu Republike Hrvatske.

Općeniti problemi razvoja malog poduzetništva, uključujući nedostatak znanja i tehnologija, neadekvatne izvore financiranja i probleme u funkcioniranju pravne države - izrazito pogađaju i zadruge. U zadruge se često udružuju mikro-poduzetnici koji nisu konkurentni za samostalan nastup na tržištu, koji djeluju u nisko-profitabilnim djelatnostima te u ruralnim i/ili slabije razvijenim područjima. Pojedine tipove zadruga pogađaju i posebni problemi: neuređenost tržišta poljoprivrednih proizvoda što otežava poslovanje poljoprivrednih zadruga, manjkavosti stambene politike onemogućile su zamah stambenih zadruga, a malverzacije pojedinih štedno-kreditnih zadruga odrazile su se na taj segment zadrugarstva.

Zadruge uglavnom obuhvaćaju raznorodne djelatnosti u kojima prevladavaju uglavnom nabavno-prodajne, a manje proizvođačko-prerađivačke aktivnosti. Kvaliteta upravljanja zadrugama je nedostatna, a one su slabo integrirane u tržište roba i još manje u tržište kapitala. Većina poljoprivrednih gospodarstava uključenih u zadruge doživljava ih kao "izlaz" pri otežanoj ponudi njihovih proizvoda u odnosu na pojedinačno djelovanje. Kao sljedeća prednost navodi se sloboda poduzetništva na vlastitom gospodarstvu i mogućnost poslovne suradnje poljoprivrednim gospodarstvima u područjima u kojima su ona poslovno najslabija (pristup tržištu, marketing, distribucija). Na trećem mjestu ispitanici stavljaju zaštitu od nabave nekvalitetne robe i visokih maloprodajnih cijena. Osnaživanje opće poslovne sigurnosti kroz zadrugu i zadružno organiziranje te zajedništvo, ispitanici stavljaju na posljednje mjesto u svojim prioritetima iako je zajedništvo temeljni atribut zadruge kao poslovne asocijacije (Tratnik i sur, 2007.).

\section{Zaključak}

U Hrvatskoj, koja ima temelje i tradiciju zadrugarstva, postoji velik prostor za snažniji 'vjetar u leđa' razvoju zadrugarstva, u skladu s europskom politikom i promocijom načela socijalne ekonomije. 
Analizom strukture sektora zadrugarstva i socijalne ekonomije u Hrvatskoj, zaključuje se da je ovaj oblik organizacija najučestaliji u poljoprivrednom sektoru. To je i razumljivo i sukladno iskustvu europskih zemalja. Ipak, kada je riječ o zadrugama u industrijskom i uslužnom sektoru, stanovanju i financijskom sektoru, Hrvatska bitno zaostaje za europskim tendencijama. Analiza indikatora poslovanja sektora zadrugarstva pokazuje upravo da su i u Hrvatskoj rentabilnost i ekonomičnost poslovanja veći upravo u spomenutim uslužno-industrijskim zadrugama. Stoga bi bilo važno poticajno djelovati upravo na ove oblike zadružnog organiziranja u Hrvatskoj. Usporedno s prethodnim važno je također i nadalje poticati i osnaživati oblike zadružnog organiziranja u poljoprivrednom sektoru.

Aktualna strategija razvoja Europske unije 'Europe 2020.' koja je lansirana u ožujku 2010. godine od strane Europskog Vijeća donosi smjernice za pojedina područja, a izričito spominje sektor socijalne ekonomije i to unutar područja koje se bavi promocijom socijalnog uključivanja i borbom protiv siromaštva. Smjernica 10 navodi kako zemlje članice trebaju promovirati puno sudjelovanje u društvu i gospodarstvu te proširivati mogućnosti za zapošljavanje, koristeći sredstva Europskog socijalnog fonda te da je potrebno promovirati pristup socijalne ekonomije $i$ socijalnih inovacija kako bi se pomoglo najrizičnije skupine društva (http://ec.europa. eu/eu2020/). Temeljem navedene smjernice nositelji ekonomske i socijalne politike u Hrvatskoj trebaju formulirati institucionalna rješenja te poticati i jačanje svijesti o zadrugarstvu, kao i razvoj sektora zadrugarstva i socijalne ekonomije. Prilagođavanjem zakona i instrumenata ekonomske i socijalne politike i učinkovitim djelovanjem nadležnih tijela može se dati snažnu potporu razvoju gospodarskih subjekata koji svoje poslovanje temelje na principima zadrugarstva i socijalne ekonomije. Usporedno je potrebno edukacijskim i promotivnim aktivnostima zadruge razdvojiti od asocijacija koje ih povezuju sa 'socijalističkim reliktom' i promovirati ih kao suvremen i djelotvoran način ekonomske organizacije. Naprotiv, ovakvi oblici organiziranja imaju snažnu potporu od strane europskih institucija zato što simultano polučuju i ekonomske i socijalne učinke, odnosno doprinose ekonomskoj aktivnosti, zapošljavanju i socijalnoj koheziji društva.

Prostor za rast sektora zadrugarstva u Hrvatskoj na temelju usporedbe s europskim pokazateljima je velik. Kako se vidi iz prikazanih i obrađenih podataka Republika Hrvatska uvelike zaostaje i po udjelu članova zadrugara u ukupnom broju stanovnika i po udjelu zaposlenih sektora zadrugarstva u ukupnom aktivnom stanovništvu. Potonji pokazatelj se za Republiku Hrvatsku u 2009. godini kretao na razini od oko 0,2 \%, a primjerice u Italiji isti udio iznosi 5\%, u Francuskoj je veći od 3\%, a u najvećem broju članica Europske unije ovaj pokazatelj se kreće između 2 i 3\%. Primjerice, kada bi se taj pokazatelj u Hrvatskoj popeo na 2\%, sektor zadrugarstva trebao bi imati više od 30.000 zaposlenih, odnosno oko deset puta više nego danas. Ove brojke najbolje ilustriraju potencijal za rast ovog zanemarivanog sektora u Hrvatskoj i njegov socio-ekonomski značaj.

Postojanje i djelovanje zadruga značajno doprinosi poboljšanju nekoliko bitnih segmenata gospodarstva. Kvalitetna povezanost i upravljanje zadrugama dovodi 
do bolje poslovne efikasnosti članova zadruga i olakšava im razvoj poslovanja. Udruživanje u zadruge može otvoriti vrata mnogim malim poduzetnicima da izađu na nova tržišta, prošire proizvodnju, poboljšaju profitabilnost i kvalitetu proizvoda - a da pritom osiguraju nova radna mjesta, prošire prostor društvene suradnje i daju doprinos uravnoteženijem regionalnom razvoju Hrvatske. Snažniji razvoj zadrugarstva i socijalne ekonomije poboljšao bi ukupnu gospodarsku efikasnost u Hrvatskoj te pozitivno utjecao na kreiranje socijalno osjetljivijeg modela ukupnog ekonomskog razvoja.

\section{Literatura}

Avsec F. (2005). Poljoprivredne zadruge u Republici Sloveniji. Sociologija sela, 43 (1):83-108. Bateman M. i Maleković, S. (2003). Potpora razvoju zadrugarstva u Hrvatskoj. CARDS program Europske unije za Hrvatsku.

Borzaga C. and Spear R. (2004). Trends and challenges for co-operatives and social enterprises in developed and transition countries. Trento: Fondazione Cariplo.

Cooperatives Europe Asbl. (2010). "European Co-operatives Key Statistics 2009”. Brussels: Cooperatives Europe Asbl.

Cooperatives Europe; EUCRISE (European Research Institute on Cooperative and Social Enterprises) i EKAI CENTER (2010). Study on the implementation of the Regulation 1435/2003 on the Statute for European Cooperative Society (SCE). Final Study Executive Summary and Part I: Synthesis and comparative report, Brussels.

COUNCIL DIRECTIVE 2001/86/EC of 8 October 2001 supplementing the Statute for a European company with regard to the involvment of employees (2001). Official Journal of the European Communities, Luxembourg.

COUNCIL REGULATION (EC) No 1435/2003 of 22 July 2003 on the Statute for a European Cooperative Society (SCE) (2003). Official Journal of the European Communities, Luxembourg.

European Commission (2010). Europe 2020 - A strategy for smart, sustainable and inclusive growth. Brussels: European Commission. Pregledano 15. 1. 2011. (http://ec.europa.eu/ eu2020/).

European Commission (2011). Enterprise and Industry; Small and medium-sized enterprises (SMEs); Co-operatives. Pregledano 5. 1. 2011. (http://ec.europa.eu/enterprise/policies/ sme/promoting-entrepreneurship/social-economy/co-operatives/index_en.htm).

Hansmann, H. (1999). Cooperative firms in theory and practice. The Finnish Journal of Business Economics, 4: 387-403.

Hrvatski savez zadruga (2010). Podaci i financijki pokazatelji poslovanja zadružnog sektora u Hrvatskoj od 2005. do 2009. godine.

ISSAN (2004). Trends and challenges for co-operatives and social enterprises in developed and transition countries. Trento: ISSAN.

MacPherson, I. (1995). Co-operative Principles for the 21st Century. Geneva: ICA.

Muenkner, H. (2003). Trends in European Cooperative Movement. Selected Readings for MCE 5. Nugool Kornyuenyong.

Nilsson, J. (2001). Organizational principles for co-operative firms. Scandinavian Journal of Management, 17: 329-356.

Vanhuynegem, P. (2008). Issues and trends in cooperative reform. Dar es Salaam: ILO/ COOPAfrica. 
Tratnik M.; S. Radinović i Đ. Žutinić. (2007). Zadrugarstvo Hrvatske: Izazovi stabilnosti poljoprivrednih gospodarstava, Agronomski glasnik 1/2007.

Tratnik, M.; Stracenski, M. i Radinović, S. (2005). Zadrugarstvo: čimbenik stabilnosti, kompetitivnosti i konkurentnosti malih poljoprivrednih gospodarstava. Sociologija sela, 43: 195-213.

Zakon o kreditnim unijama. Narodne novine, 141/2006. 
Overview scientific work

Zdenko Babić

Faculty of Law in Zagreb

Department of Social Work

zbabic@pravo.hr

Domagoj Račić

Mreža znanja d.o.o.

domagoj.racic@mrezaznanja.hr

\title{
Co-operatives and Social Economy in Croatia: Trends, Indicators and Prospects in the European Context
}

\begin{abstract}
Although co-operatives and social economy in Croatia have a long tradition, the periods of socialism and transition have had negative effects on their development. Based on an analysis of key indicators of business performance of co-operatives in Croatia, this paper provides an assessment of current state of affairs in this sector of the Croatian economy. Moreover, the paper provides insights into the state of affairs and current trends in this area in European countries. On the basis of the comparison of the state of affairs of cooperatives and social economy in Croatia and European countries, potentials and recommendations are outlined. The recommendations, which are addressed to economic and social policy makers, are made in order to optimise the future development of this sector in Croatia.
\end{abstract}

Key words: co-operatives, social economy, Croatia 